Naskah diserahkan:26-08-2021; Direvis: 08-11-2021; Diterima: 11-11-2021

\section{Analisis Hukum Atas Ujaran Rasis di Asrama Papua Surabaya}

Huzaiman, Ma'ruf Akib

Prodi IImu Hukum, Universitas Muhammadiyah Kendari

Email: maeroef@gmail.com

\begin{abstract}
ABSTRAK: Bertindak bijaksana perlu, bahkan ketika berbicara. Jika tidak terkontrol, maka ujaran yang terlontar akan menyinggung pihak lain. Ujaran kebencian (ungkapan verbal, tindakan fisik, bahkan destruktif) harus dihindari karena respon yang diberikan oleh penerima ujaran. Analisis hukum atas ujaran rasis di asrama Papua di Surabaya meliputi: pelaku pelecehan bendera, aparat harusnya bertindak profesional, pelaku ujaran rasial pada saat kejadian, pelecehan bendera dengan ujaran rasis dua hal yang berbeda. Adapun kesimpulan penulis yaitu: bahwa dampak yang ditimbulkan atas reaksi massa di asrama Papua Surabaya terbukti telah menimbulkan kerugian persoalan sosial luar biasa dan ancaman disintegrasi bangsa. Berdasarkan hal-hal yang telah dikaji di atas, terbukti intrumen hukum cukup tersedia untuk menjatuhkan sanksi baik pidana badan ataupun denda. Harus ada ada sanksi yang mampu mengakomodir rasa keadilan masyarakat terhadap mereka yang terbukti bersalah agar tindakan serupa tidak terjadi kembali di masa yang akan datang.
\end{abstract}

Kata kunci: Ujaran Kebencian; Rasis; Papua.

ABSTRACT: Acting wise need, even when talking. If it is not controlled, the speech that comes out will mention other parties. Hatred said (verbal expression, physical action, even destructive) must be avoided because of the response given by the recipient of the speech. Legal analysis of racist speeches in the Papua Dormitory in Surabaya includes: the perpetrators of flag harassment, the apparatus should act professionally, the perpetrators of racial speech at the time of the incident, default flag with racist speech two different things. The conclusion of the author is: that the impact caused by mass reactions in the Papua Dormitory Surabaya has been proven to have losses of extraordinary social issues and the threat of the nation's disintegration. Based on the things that have been reviewed above, it is proven that legal instruments are quite available to impose sanctions both criminal bodies or fines. There must be sanctions that can accommodate a sense of public justice to those who are found guilty so that similar actions do not occur back in the future.

Keywords: Hate Speech, Racism; Papua.

\title{
PENDAHULUAN
}

Dalam setiap ujaran seseorang sudah seharusnya mengacu pada etika agar tidak mendapat respon negatif bagi mereka yang menerima ujaran tersebut. Kebebasan berbicara bagi seseorang bukan dilaksanakan secara 
semena-mena karena jika tidak terkontrol maka ujaran yang terlontar kemungkinan akan menyinggung pihak lain. Hal inilah yang harus dihindari karena respon yang diberikan oleh penerima ujaran itu akan bermacam-macam. Dapat direspon secara pasif atau diam tetapi bisa juga dengan ungkapan verbal, tindakan fisik bahkan tindakan destruktif. Respon yang diberikan tergantung seberapa besar rasa kecewa yang dialami oleh korban ujaran yang merugikan tersebut.

Di alam demokrasi sekarang ini ujaran merupakan bagian dari kebebasan berbicara atau berpendapat. Akan tetapi, kebebasan yang diberikan harus diimplementasikan secara bijaksana. Jangan heran jika ujaran itu direspon negatif oleh massa maka akan membuka konflik sosial. Secara filosofis dalam konteks kemanusiaan, kebebasan menyampaikan ujaran disampaikan secara santun karena pada dasarnya manusia itu beradab. Sebagai manusia yang beradab maka etika merupakan pegangan dalam hidup bermasyarakat. Tindakan yang demikian dalam kehidupan berbangsa dan bernegara di Indonesia rujukannya adalah Pancasila. Tidak mengherankan dalam Undang-Undang Dasar Negara Republik Indonesia Tahun 1945 sebagai konstitusi negara memang menjamin kebebasan menyampaikan pendapat. Karena dijamin oleh konstitusi dengan sendirinya menjadi hak konstitusional warga negara.

Ujaran dapat saja menjadi bagian dari penyampaian pendapat, sehingga dari aspek Hak Asasi Manusia di Indonesia harus tunduk pada Undang-Undang Nomor 39 Tahun 1999 tentang Hak Asasi Manusia, dimana Pasal 23 ayat( 2) menyatakan:

"Setiap orang bebas untuk mempunyai, mengeluarkan dan menyebarluaskan pendapat sesuai hati nuraninya, secara lisan dan atau tulisan melalui media cetak maupun elektronik dengan memperhatikan nilai-nilai agama, kesusilaan, ketertiban, kepentingan umum, dan keutuhan bangsa"

Kebebasan yang diberikan secara hukum ini ternyata kurang dilakukan secara bijaksana. Sebuah ujaran yang dilontarkan dengan semena-mena bahkan cenderung di luar kontrol yang bersangkutan. Inilah akibatnya, karena ujaran dimaksud bersifat spontan oleh yang mengujarkan maka yang terjadi respon yang negatif bagi yang menerima ujaran. Kondisi yang demikian terlihat nyata jika kita membaca apa yang disajikan oleh pers dalam bulan ini. Sebuah ujaran rasis di Surabaya telah terjadi. Sebuah ujaran yang mengandung rasisme (ucapan penyerangan secara fisik) dilontarkan di hadapan asrama mahasiswa Papua Kota Suarabaya, Provinsi Jawa Timur. Di provinsi Papua dan Papua Barat warga Papua yang merasa tersinggung memberikan reaksi dengan unjuk rasa besar-besaran bahkan cederung bertindak destruktif. Perkantoran dan fasilitas umum menjadi sasaran kemarahan massa. Bangunan-bangunan yang dibiayai dengan anggaran negara yang besar rusak akibat keberingasan massa.

Sebuah ujaran baik dilontarkan secara spontan atau emosional jika hal itu sifatnya rasis jelas akan memancing reaksi sisi-sisi kemanusiaan bagi mereka 
yang tersinggung. Tidak bisa budaya lokal setempat yang menganggap lontaran spontan sebagai sesuatu yang ditolerir meski itu rasis. Hak asasi seseorang adalah bebas mengemukakan ujaran tetapi ujaran tersebut juga dibatasi oleh hak asasi orang lain. Harusnya tidak boleh semena-mena dalam berujar ke pihak lain meskipun itu di daerah sendiri. Respon negatif diberikan karena ucapan tersebut dinilai tidak sepatutnya diuraikan apalagi di hadapan publik, dan dengan sendirinya yang merasa dirugikan menjadi tersinggung.

\section{METODE PENELITIAN}

Penelitian ini merupakan penelitian kepustakaan karena penulis mengumpulkan data melalui dokumen-dokumen, baik dokumen tertulis, fotofoto, gambar, maupun dokumen elektronik yang dapat mendukung dalam proses penulisan.Penulis mengumpulkan berita yang terkait Ujaran Rasis di Asrama Papua Surabaya dari news.detik.com, metro news, dan tribunnews.com. Di samping itu, buku-buku dan artikel-artikel yang relevan digunakan sebagai bahan elaborasi. Adapun tahapan-tahapan yang dilalui oleh peneliti adalah: pemilihan topik (pelaku pelecehan bendera, aparat harusnya bertindak profesional, pelaku ujaran rasial pada saat kejadian, pelecehan bendera dengan ujaran rasis dua hal yang berbeda), eksplorasi infromasi, menentukan fokus penelitian, pengumpulan sumber data, persiapan penyajian data, dan penyusunan laporan

\section{HASIL PENELITIAN DAN PEMBAHASAN}

Masalah rasisme yang terjadi yang dilontarkan oleh massa yang mendatangi asrama mahasiswa Papua di jalan Kalasan nomor 10 Surabaya, Jawa Timur, Indonesia pada hari Jumat 16 Agustus 2019 cukup menyita perhatian masyarakat Indonesia. Atas kejadian ini orang kemudian berpaling kepada hukum sejauhmana efektifitasnya meredam masalah ujaran rasis ini. Hal ini penting karena menyangkut hak asasi yang melekat pada diri setiap orang. Peristiwa yang memprihatinkan ini seharusnya terjadi jika hukum mampu mengakomodir persoalan rasisme yang timbul di Indonesia.

Awal kejadiannya dimulai dengan kabar telah terjadi pelecehan bendera kebangsaan Republik Indonesia merah putih. Kabarnya bendera itu dibuang diselokan depan asrama mahasiswa Papua di jalan Kalasan nomor 10 Surabaya, Jawa Timur.

Menurut Humas Polda Jatim, Kombes Pol Frans Barung Mangera, ada sekiat 700 hingga 1000 massa mendatangi asrama mahasiswa tersebut. Massa tersebut terprovokasi oleh kabar pelecehan bendera tersebut. Di sisi lain mahasiswa di dalam asrama Papua memasang atribut tertentu yang membuat massa makin terpancing. Pihak kepolisian kemudian melakukan evakuasi 43 mahasiswa Papua karena situasi yang sulit dikendalikan pada sekitar pukul 13.00 WIB. Selanjutnya, dalam aksi massa pada 17 Agustus 2019, muncul ujaran-ujaran rasial yang disebut memicu aksi kerusuhan di sejumlah daerah di Papua dan Papua Barat.

Berdasarkan hal-hal yang telah didiskripsikan diatas maka menarik kiranya untuk melakukan kajian analisis hukum atas ujaran rasis di asrama Papua 
di Surabaya tersebut. Aspek-aspek yang coba dianalisis meliputi hal-hal berikut ini:

\section{Pelaku Pelecehan Bendera}

Sebagaimana telah diketahui bahwa kasus rasisme ini diawali oleh adanya isu bahwa telah terjadi pelecehan atas simbol negara bendera merah putih. Menjadi penting kiranya untuk mencari siapa sebenarnya pelaku pelecehan bendera tersebut. Tanpa dimulainya tindakan pelaku membuang bendera bendera di selokan dengan sendirinya tidak ada tindakan pengepungan massa di asrama mahasiswa Papua di Surabaya. Tanpa adanya kehadiran masa di hari kejadian itu sudah barang tentu tidak akan pernah muncul ujaran rasial diantara kerumunan massa itu.

Secara hukum tindakan membuang bendera ke selokan jelas merupakan penghinaan atas bendera itu sendiri. Bagi mereka yang memiliki patriotisme yang tinggi terhadap bangsanya sudah barang tentu akan bereaksi atas tindakan penghinaan bendera itu. Mengatisipasi gejolak yang terjadi maka aparat harus bergerak cepat mencari pelaku karena instrumen hukum untuk menindak pelaku penghinaan bendera cukup tersedia.

Ketentuan hukum bagi mereka yang telah menodai bendera kebangsaan Republik Indonesia telah diatur sebagai mana Pasal 154a Kitab Undang-Undang Hukum Pidana (KUHP):

"Barang siapa menodai Bendera Kebangsaan Republik Indonesia dan Lambang Negara Republik Indonesia, dihukum dengan hukuman penjara selama-lamanya empat tahun atau denda setinggi-tingginya tiga ribu rupiah."

Jika menelaah lebih jauh atas Pasal 154a KUHP tersebut maka pelaku atas penodaan bendera itu berlaku pada siapa pun tanpa pandang bulu. Harusnya tidak ada keraguan untuk menindak si pelaku.

Ketentuan pidana atas perbuatan menghina bendera kebangsaan Indonesia ini juga diatur dalam Undang-Undang Republik Indonesia Nomor 24 Tahun 2009 Tentang Bendera, Bahasa, dan Lambang Negara, Serta Lagu Kebangsaan, merupakan simbol kedaulatan dan kehormatan negara (UU No.24 Tahun 2009). Menurut Ketentuan tersebut, mereka yang bertindak membuang bendera ke selokan dapat dijerat Pasal 57 huruf a UU No. 24 Tahun 2009: "Setiap orang dilarang mencoret, menulisi, menggambari, atau membuat rusak lambang negara dengan maksud menodai, menghina, atau merendahkan kehormatan lambang negara".

Tindakan membuang bendera merah putih ke selokan jelas merupakan tindakan merendahkan kehormatan bendera sebuah bangsa sebagai sebuah lambang negara. Sanksi hukumnya bagi pelanggarnya selanjutnya diatur oleh Pasal 68 UU No.24 Tahun 2009: 
"Setiap orang yang mencoret, menulisi, menggambari, atau membuat rusak Lambang Negara dengan maksud menodai, menghina, atau merendahkan kehormatan Lambang Negara sebagaimana dimaksud dalam Pasal 57 huruf a, dipidana dengan pidana penjara paling lama 5 (lima) tahun atau denda paling banyak Rp500.000.000,00 (lima ratus juta rupiah),"

Upaya untuk mengungkap pelaku yang membuang bendera ke selokan di depan asrama mahasiswa Papua di Surabaya sebelum terjadinya pengepungan asrama mahasiwa di Papua tidak terpecahkan. Jika terpecahkan maka aksi pengepungan oleh massa di asrama Papua itu tidak terjadi. Massa paling tidak akan memintai tangungjawab pelaku atas perbuatannya itu. Dengan sendirinya kecil kemungkinan terjadi ujaran rasis mengemuka ke publik yang memicu kerusuhan besar di Papua dan Papua Barat.

\section{Aparat Harusnya Bertindak Profesional}

Dalam insiden pengepungan asrama mahasiswa Papua di Surabaya, keterlibatan aparat negara harus bertindak profesional. Dalam peristiwa itu ada dua pihak yang saling berhadapan. Di satu sisi massa yang berjumlah 700 sampai 100 orang yang merasa terganggu atas insiden pelecehan bendera, di sisi lain mahasiswa Papua yang hendak dimintai pertangungjawaban oleh massa justru membawa atribut yang justru memancing emosi. Diantara dua pihak yang saling berhadapan itu seharusnya aparat bersikap netral bukan justru terpancing dan bertindak emosional.

Aparat yang hadir dalam insiden ini terbukti bahwa baik sipil atau militer terbukti tidak bersikap profesional. Mereka justru larut dalam situasi sehingga emosi bahkan ada yang berteriak rasis. Fakta yang terjadi berdasarkan keterangan Kapendam V/Brawijaya, Letkol Imam Haryadi ada Lima anggota TNI yang mendapat skorsing sementara itu yakni Komandan Koramil Tambaksari Mayor Inf N H Irianto bersama empat personel Koramil lainnya. Tak hanya dari aparat militer yang ditindak, seorang aparat trantib tingkat kecamatan, bernama Syamsul Arifin, oleh kepolisian ditetapkan sebagai tersangka ujaran rasis.

Tindakan skorsing bagi aparat militer merupakan bentuk penegakkan disiplin secara institusional. Tindakan ini lebih menyangkut pada etika profesi kepada oknum aparat militer. Hal ini membuktikan bahwa pemeriksaan terhadap oknum belum menemukan alat bukti yang cukup untuk ditindak secara hukum. Sementara kepada aparat trantib kecamatan pihak kepolisian setidak-tidaknya telah memiliki dua alat bukti yang cukup untuk menindak secara hukum. Faktanya aparat trantib tersebut telah ditetapkan sebagai tersangka. Baik penegakan etika profesi atau hukum yang diberlakukan bagi militer dan non militer bentuk dari penegakkan aturan sebagai bagian dari tata cara pergaulan dalam masyarakat manusia. Hal ini penting demi tercapainya keamanan dan ketertiban dalam sebuah lingkungan masyarakat. 


\section{Pelaku Ujaran Rasial pada Saat Kejadian}

Pelaku ujaran rasial ketika terjadi aksi pengepungan asrama mahasiswa Papua di Surabaya merupakan menjadi faktor pemicu terhadap reaksi yang ditunjukkan oleh massa di Papua dan Papua Barat. Hal ini diyakini karena massa di Papua dan Papua Barat bereaksi karena salah satunya adalah adanya ujaran rasial. Seharusnya tanpa ujaran rasial maka tidak ada yang merasa terhina atau direndahkan. Sikap rasialis yang ditunjukan justru mengancam kebhinekaan Indonesia.

Suatu ujaran yang bersifat rasial dengan sendirinya akan memicu permusuhan terhadap pihak yang dituju oleh ujaran dimaksud. Ujaran yang demikian harus disikapi agar tidak mengganggu ketertiban dan ketentraman masyarakat. Jika merujuk pada Kitab Undang-Undang Hukum Pidana, di dalam Pasal 156, telah dinyatakan:

“1) Barang siapa di muka umum menyatakan permusuhan, kebencian atau meremehkan (minacthing) terhadap suatu atau beberapa golongan rakyat Indonesia, diancam dengan pidana penjara maksimum empat (4) tahun atau pidana denda paling banyak empat ribu lima ratus rupiah.

(2) Yang diartikan dengan golongan untuk pasal ini dan pasal berikutnya ialah tiap bagian dari penduduk Indonesia yang berbeda dengan bagian atau beberapa bagian lainya karena suku-bangsa (ras), adat-istiadat, agama, daerah asal, keturunan, kebangsaan (nasionalitas) atau kedudukan menurut hukum tata Negara."

Jerat pidana bagi seorang rasialis bukan hanya ditemukan di Kitab Undang-Undang Hukum Pidana, saja. Ketentuan dalam Undang-Undang Nomor 40 Tahun 2008 tentang Penghapusan Diskriminasi Ras dan Etnis, juga memberikan ancaman pidana maupun denda, dimana dalamnya ada Pasal 16 yang menyatakan:

"Setiap orang yang dengan sengaja menunjukkan kebencian atau rasa benci kepada orang lain berdasarkan diskriminasi ras dan etnis sebagaimana dimaksud dalam Pasal 4 huruf b angka 1, angka 2 atau angka 3, dipidana dengan pidana penjara paling lama 5 (lima) tahun dan/atau denda paling banyak Rp. 500.000.000,00 (lima ratus juta rupiah)."

Akan tetapi, ujaran rasial tidak hanya dilakukan di dunia nyata seperti yang dilakukan oknum di Surabaya tersebut. Ujaran kebencian ternyata di dunia modern sekarang ini dapat dilakukan di dunia maya. Bukan berarti ujaran kebencian di dunia maya tidak menimbulkan permasalahan di dunia nyata. Harus diakui bahwa ujaran di dunia maya merupakan salah satu bentuk komunikasi yang tidak terikat jarak dan waktu. Ketika komunikasi dunia maya terjadi berupa ujaran rasial menimbulkan kemarahan sudah barang tentu akan dilampiaskan di dunia nyata.

Ujaran rasial di dunia maya haruslah dimaknai sebagai informasi yang ditujukan untuk menimbulkan rasa kebencian atau permusuhan. Informasi yang 
demikian sangat rentan untuk memicu keresahan di masyarakat yang pada akhirnya berpotensi menimbulkan kerugian materiil mapun non materiil di dunia nyata. Oleh karenanya sehubungan dengan informasi yang ditujukan untuk menimbulkan rasa kebencian atau permusuhan maka ada instrumen hukumnya yakni Undang-Undang Informasi dan Transaksi Elektronik. Terkait informasi yang ditujukan untuk menimbulkan rasa kebencian atau permusuhan, Pasal 28 ayat (2) dan Pasal 45 ayat (2) Undang-Undang Nomor 19 Tahun 2016 tentang Perubahan atas Undang-Undang Nomor 11 Tahun 2008 tentang Informasi dan Transaksi Elektronik "Pasal 28 ayat (2):

"Setiap orang dengan sengaja dan tanpa hak menyebarkan informasi yang ditujukan untuk menimbulkan rasa kebencian atau permusuhan individu dan/atau kelompok masyarakat berdasarkan atas suku, agama, ras dan antargolongan (SARA).

Sementara itu, Pasal 45 ayat (2):

"Setiap orang yang memenuhi unsur sebagaimana dimaksud dalam Pasal 28 ayat (1) atau ayat (2) dipidana dengan pidana penjara paling lama 6 (enam) tahun dan/atau denda paling banyak Rp. 1.000.000.000,00,- (Satu miliar rupiah)"

Inilah yang terjadi ketika insiden pengepungan asrama Papua di Surabaya di unggah di dunia maya maka masyarakat di Papua dan Papua Barat menujukkan reaksinya. Akibatnya, kerusuhan massal pun terjadi di Papua dan Papua Barat meskipun tidak secara keseluruhan. Akibat kerusuhan yang terjadi menimbulkan korban nyawa dan materi yang bernilai milyaran. Atas ujaran rasial yang dipicu di dunia maya sudah seharusnya juga mendapat tindakan hukum

\section{Pelecehan Bendera dengan Ujaran Rasis Dua Hal yang Berbeda}

Yang sangat disayangkan ujaran yang bersifat rasial telah menimbulkan reaksi yang merugikan secara moril mapun materiil. Bahkan yang lebih mengkhawatirkan justru menimbulkan disintegrasi bangsa. Reaksi massa dari warga lokal yang mendatangi asrama mahasiswa Papua terlihat emosional. Aparat kepolisian yang kini menangani masalah ini menilai ada tindakan provokasi. Yang jelas ada atau tidak provokasi tersebut, faktanya ada ujaran rasis hal ini terdengar dan terlihat nyata dalam video-video yang diunggah di media sosial.

Hal yang sangat disayangkan adalah rekaki massa atas isu pelecehan bendera dengan meneriakkan isu rasis. Hal ini menandakan bahwa massa yang mendatangi asrama Papua di Surabaya tersebut sudah diliputi perasaan emosional sehingga bertindak irasional. Seandainya mereka tidak diliputi emosi akan bertindak logis sehingga pelecehan bendera tidak dilawan dengan sikap rasialis. Dengan pikiran yang jernih sudah barang tentu kita mampu memilah 
bahwa masalah pelecehan bendera dan ujaran rasialis merupakan dua hal yang berbeda.

Dipahami kemudian bahwa pelecehan bendera dan ujaran rasialis diatur dalam perundangan yang berbeda. Jika menyangkut pelecehan bendera diatur dalam Pasal 154a Kitab Undang-Undang Hukum Pidana (KUHP) serta UndangUndang Republik Indonesia Nomor 24 Tahun 2009 Tentang Bendera, Bahasa, dan Lambang Negara, Serta Lagu Kebangsaan bendera merupakan simbol kedaulatan dan kehormatan negara. Di sisi lain ujaran rasial intrumen perundangannya meliputi, Pasal 156 Kitab Undang-Undang Hukum Pidana, Pasal 16 UndangUndang Nomor 40 Tahun 2008 tentang Penghapusan Diskriminasi Ras dan Etnis, kemudian pada Pasal 28 ayat (2) dan Pasal 45 ayat (2) Undang-Undang Nomor 19 Tahun 2016 tentang Perubahan atas Undang-Undang Nomor 11 Tahun 2008 tentang Informasi dan Transaksi Elektronik. Perundangan ini haruslah dimaknai sebagai hukum yang berfungsi menjaga dan memelihara hubungan sosial.

Menyikapi dua permasalahan yang berbeda dalam kasus di Surabaya ini maka dibutuhkan sikap tidak emosional disertai adanya kesadaran hukum bagi setiap warga negara. Dengan tidak emosional membuak ruang untuk berpikir jernih. Demikian halnya dengan memiliki kesadaran hukum yang tinggi maka reaksi yang di berikan atas suatu masalah akan senatiasa mengikuti ramburambu hukum yang berlaku.

\section{SIMPULAN}

Dampak yang ditimbulkan atas reaksi massa di asrama Papua terbukti telah menimbulkan kerugian persoalan sosial luar biasa dan ancaman disintegrasi bangsa. Berdasarkan hal-hal yang telah dikaji di atas, terbukti intrumen hukum cukup tersedia untuk menjatuhkan sanksi baik pidana badan ataupun denda. Harus ada ada sanksi yang mampu mengakomodir rasa keadilan masyarakat terhadap mereka yang terbukti bersalah agar tindakan serupa tidak terjadi kembali di masa yang akan datang.

\section{UCAPAN TERIMAKASIH}

Penulis menyampaikan ucapan terimakasih kepada seluruh pihak yang telah ikut berkontribusi dalam menyusunan artikel ini, khususnya kepada seluruh Tim Editor Jurnal IImu Manajemen Sosial Humaniora, LP3M Universitas Muhammadiyah Kendari.

\section{DAFTAR PUSTAKA}

Dossy Iskandar Prasetyo dan Bernard L. Tanya. (2011). Hukum Etika dan Kekuasaan. GENTA PUBLISHING:Yogyakarta.

Hilda Meilisa Rinanda,2019,Soal Ucapan Rasis kepada Mahasiswa Papua, Staf Kecamatan Ngaku Spontan, https://news.detik.com/ berita- jawa timur/d-4691320/soal-ucapan-rasis-kepada-mahasiswa-papua-stafkecamatan-ngaku- spontan, diakses Jumat 6 September 2019 
https ://www. youtube. Com/watch?v= bgGvYeN2OI, diakses Jumat 6 September 2019

https://www.tribunnews.Com/regional/2019/08/29/terbaru-kasus-rasismemahasiswa-papua-di-surabaya-peran-tri-susanti-yang-membuatnyajadi-tersangka?page=2, diakses Jumat 6 September 2019.

https://www.tribunnews.com/regional/2019/08/29/terbaru-kasus-rasismemahasiswa-papua-di-surabaya-peran-tri-susanti-yang-membuatnya-jaditersangka?page=4, diakses Sabtu 7 September 2019

https://www.tribunnews.com/nasional/2019/09/04/sosok-syamsul-arifintersangka-kasus-rasisme-di-asrama-mahasiswa-papua-kini-ditahan-danminta-maaf, diakses Sabtu 7 September 2019

I Dewa Gede Palguna, PENGADUAN KONSTITUSIONAL (CONSTITUTIONAL COMPLAINT) Upaya Hukum terhadap Pelanggaran Hak-hak Konstitusional Warga Negara. Sinar Grafika: Jakarta.

Soetandyo Wignjosoebroto. (2002). Hukum: Paradigma, Metode dan Masalah. ELSAM dan HUMA:Jakarta

Undang-Undang Dasar Negara Republik Indonesia Tahun 1945

Undang-Undang Nomor 19 Tahun 2016 tentang Perubahan atas Undang-Undang Nomor 11 Tahun 2008 tentang Informasi dan Transaksi Elektronik

Undang-Undang Republik Indonesia Nomor 24 Tahun 2009 Tentang Bendera, Bahasa, dan Lambang Negara, Serta Lagu Kebangsaan

Undang-Undang Nomor 40 Tahun 2008 tentang Penghapusan Diskriminasi Ras dan Etnis

Undang-Undang Nomor 39 Tahun 1999 tentang Hak Asasi Manusia

Kitab Undang-Undang Hukum Pidana 